\section{COSTS OF ELECTRICAL HEATING}

$\mathrm{N}$ Electrical Industries of November, Mr. F. D. 1 Parker criticizes methods of measuring the running costs of electricity when used for heating and cooking installations. If the estimates given are too high, the company loses a valuable load; and if too low, there is often dissatisfaction and complaints. In particular, the estimating of 'space heating' loads is especially difficult owing to the fact that so much depends on many undeterminable factors.

Weather conditions are very closely related to energy consumption in much the same way as the amount of hot water used determines electric waterheating consumption. The main difficulty is that whereas the latter can in some measure be computed, the former is always conjectural. It has also to be remembered that running costs of heating installations in the south of England cannot be considered representative of those in the north, where more severe weather conditions are experienced. This emphasizes that data obtained from other installations, when not in the same locality, must be employed with caution.

Further factors influencing space-heating consumption are : type of building, position, heat-loss characteristics, hours of use, time of use and thermostat setting. The provision of revolving doors, springs on doors to exclude draughts and the system of ventilation adopted, if any, all appreciably affect operation costs. It follows that the estimating of space-heating consumption is a much easier matter when dealing with existing buildings than from plans of buildings to be erected. In the latter case, allowance has necessarily to be made for the drying out of buildings during the first year.

In the domestic sphere, estimating space-heating consumption is very conjectural, as the element of careless usage is always present. This, coupled with variations in consumers' habits and ideas as to the amount of heat required, usually prevent spaceheating consumption of one consumer being considered representative of other consumers even of identical characteristics. Apart from all-electric houses, etc., the majority of domestic space-heating consumers may be considered intermittent users. No difficulty therefore is likely to arise if consumers are advised of the consumption of the apparatus on various 'heats'-which should be done when appliances are purchased, especially from supply authorities.

With new all-electric consumers the position is somewhat different. Apart from thermostatic control and continuous heating, running costs are proportional to hours of usage, which often cannot be determined. If consumers therefore require some idea of annual space-heating costs, then the only arrangement is to obtain from them details as to probable usage and build up estimates accordingly, assuming $\frac{1}{2} \frac{2}{3}$ of the total loading of the heating apparatus is in use per hour. In regard to the heating of corridors, halls, etc., much depends on the type of apparatus installed and the method of control. It is advisable to eliminate hand control as much as possible, as apparatus employed for such purposes is apt to be neglected.

The calculation of operation costs on a heat loss basis for direct heating, assuming, for example, minimum outside temperatures of, say, $25-30^{\circ} \mathrm{F}$., to maintain $60^{\circ} \mathrm{F}$. internally, to obtain the required loading, and then assume average winter temperatures of, say, $40-44^{\circ} \mathrm{F}$. and arrive at the consumption accordingly, relatively to the hours of usage, heatingup times, etc., should provide reasonable estimates. The trouble is that theoretical heat-loss calculations of buildings seldom hold good in practice, owing to faulty construction, badly fitting windows and doors. Weather conditions such as effects of sun and wind should be taken into account.

\section{APPOINTMENTS VACANT}

APPIICATIONS are invited for the following appointments on or before the dates mentioned :

INSPECTOR (WOMAN) OF ScHOOLS, and an ADMINISTRATIVE AsSISTANT (MAN) - The Director of Education, Education Offices, Leeds 1 (December 31).

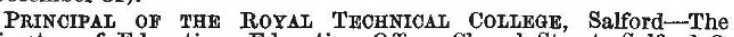
Director of Education, Education Office, Chapel Strcet, Salford 3, Lancs. (December 31).

Graddate assistant Teacher for Mechanical Engineming SuBJEoTs-The Principal, Acton Technical College, High Street, Acton, London, W.3 (January 6).

Assistant Master or Mistress for Science (mainly Mechanics, Heat and Chemistry)-The Acting Principal, Technical Institute, Sheerness.

Assistant ENGINEER For THE DRAinage AND IRRigation DEPARTMFNT, Malaya-The Crown Agents for the Colonies, 4 Millbank, London, S.W.1 (quoting $\mathrm{M} / 9316$ ).

\section{REPORTS AND OTHER PUBLICATIONS \\ (not included in the monthly Books Supplement)}

\section{Great Britain and Ireland}

British Museum (Natural History). Economic Leaflets, No. 6 : Plaster Beetles. Pp. 4. (London: British Museum (Natural History).)
[181.

Proceedings of the Royal Society of Edinburgh, Session 1939-1940. Vol. 60, Part 3, No. 23: An Analysis of the Influence of Weather upon a Migratory Movement of Birds. By Prof. James Ritchie. Pp. 299-321. 28. Vol. 60, Part 3, No. 24: Early Glacial Remajns 299-321. 28. Reindeer from the Glasgow District. By Dr. M. Macgregor and Prof James Ritchie. Pp. 322-332. 18. 3d. (Edinburgh : Robert Grant and
[2011 , LThe "Techanism of Enzyme Action". By Dr. J. H Lecture on "The Mechanism of Enzyme Action". By Dr. J. H.
Quastel. Pp. 28. (London : Institute of Chemistry.)

\section{Other Countries}

Scientifle Publications of the Cleveland Society of Natural History. Vol. 8, No. 3: On One of the Least Known of the Cleveland Shale Arthrodira. By David $\mathrm{H}$. Dunkle and Peter A. Bungart. Pp. 29-48+ plates 4-5. (Cleveland, Ohio: Cleveland Society of Natural History.) [1511

Records of the Geological Survey of India. Vol. 75, Professional Paper No. 3: Studies on some Characteristics of Indian Coking Coals By Dr. R. K. Dutta Roy. Pp. 28. (Calcutta: Geological Survey of
India.) 7 annas; $8 d$.

Field Museum of Natural History. Botænical Series, Vol. 22, No. 4: Studies of American Plants, I. By Paul C. Standley and Julian A. 4: Studies of American Plants, 1. By Paul C. Standley and Julian A. Steyermark. (Publication 480.) Pp. 219-322. (Chicago: Field Museum
of Natural History.) 75 cents.
[1911

Contributions to Embryology. Vol. 28, Nos. 170 to 178. (Publication No. 518.) Pp. iii $+451+34$ plates. (Washington, D.C.: Carnegie Institution of Washington.) [2011

U.S. Office of Education: Federal Security Agency. Bulletin, 1938, No. 14: Teaching Conservation in Elementary Schools. By Effie G. Bathurst. Pp. $v+125$. (Washington, D.C.: Government Printing Office.) 20 cents.

\section{Catalogues}

Prokayvit and Prokayvit Oral. Pp. 2. (London: The British Drug Houses, Ltd.)

The Hilger Photometric Colour Comparator (an "Abridged Spectrophotometer") with a description of the Hilger Photometric Amplifier. (SB. 289.) Pp. 8. (London: Adam Hilger, Ltd.)

Various Books, also a Compléte Set of Gould's Birds. (Catalogue No. 652.) Pp. 68. (London : Francis Edwards, Ltd.)

Early Botany and Herbals, Old Medicine and Science. (Catalogue 60.) Pp. 54. (London: E. P. Goldschmidt and Co., Ltd.)

Diary for 1941. Pp. $16+32$ maps +Diary. (Bonnybridge : John G. Stein and Co., Ltd.) 